\title{
Т.М. Дубельт
}

Одеська державна академія будівництва та архітектури, Одеса, Украӥна

\section{ДОСЛІДЖЕННЯ ВПЛИВУ ФАКТОРІВ НА ПОКАЗНИК РЕНТАБЕЛЬНОСТІ РЕКОНСТРУКЦІЇ ЖИТЛОВИХ БУДИНКІВ}

Стаття присвячена дослідженню впливу організаційно-технологічних факторів на показник рентабельності реконструкиї житлових будинків перших масових серій, при умові відселення мешканців під час проведення робіт. Мета досліджень - визначення ефективних рішень проведення реконструкції подібних будинків. В ході дослідження визначені фактори та рівні їх варіювання щзо впливають на реконструкцію житлового будинку. На основі обраної серії житлового будинку побудовані інформаційні та графічні моделі, отримані показники реконструкиії. Залежність досліджуваних показників від варійованих факторів виконана з використанням методів математичного аналізу, та представлена у вигляді діаграм залежностей. За графічним зображенням зроблені висновки щзодо ефективних рішень реконструкиії подібних об'єктів.

Ключові слова: фактори, показники реконструкції, моделі реконструкції, математичний аналіз, діаграми залежності.

\section{Постановка проблеми}

Період масового житлового будівництва почався у зв'язку з широким застосування елементів збірного залізобетону. В післявоєнний час країни колишнього СРСР (в т. ч. Україна) мали велику потребу у забезпечені населення житлом. Для вирішення цієї проблеми, починаючи з 60 років 20 століття почали масово будувати житлові будинки за типовими серіями. Проте ситуація найгострішої житлової кризи післявоєнного часу, відсутність на першому етапі досвіду проектування i будівництва таких будинків, недолік кваліфікованої робочої сили та ряд інших причин привели до створення масового житла 3 низькими споживчими якостями. Термін експлуатації таких будинків розраховувався на 25 30 років і на даний час закінчився. За статистичними даними станом на 1 січня 2011 р. загальний житловий фонд України склав 1079,5 млн.м², з них 25\% - це житлові будинки перших масових серій [1]. Обстеження будинків та визначення фізичного зносу його конструктивних частин показали, що для подовження терміну експлуатації будинків необхідна реконструкція. Незважаючи на велику кількість такого житла кількість реалізованих проєктів реконструкції на Україні обмежується двома десятками. Це пов'язано з відсутністю інформації щодо прибутковості реконструкції подібних об'єктів та небажанням інвесторів вкладати кошти в їх реалізацію. Представлені дослідження дозволяють вибрати найбільш ефективні рішення організації реконструкції, які впливають на збільшення показника рента- бельності робіт, та дозволяють зробити висновок про прибутковість реконструкції.

\section{Аналіз останніх досліджень та публікацій}

В інформаційних джерелах в більшості описані об'ємно-планувальні та конструктивні рішення таких будинків , представлені рекомендації щодо можливості їх реконструкції. Описання реалізованих проектів реконструкції на території колишнього СРСР та країн Європи [2,3.4,5] дозволило визначити основні напрямки реконструкції та перелік робіт для підвищення комфорту проживання в таких будинках. Згідно останніх досліджень та публікацій житлові будинки перших масових серій були розділені на 2 групи. До першої віднесені будинки в яких реконструкція є ефективною і дозволяє продовжити термін експлуатації [6,7]. Друга група - будинки, що вичерпали свій термін експлуатації, в силу конструктивних і експлуатаційних причин, та підлягають зносу. Описання реалізованих проєктів показало, що в ряді випадків під час виконання робіт проводилось відселення мешканців. До складу основних робіт входили: підвищення поверховості до 7 поверхів; облаштування мансардного поверху; прибудова ліфтів, сміттєпроводів; удосконалення конструкції балконів; заміна комунікацій, вікон і зовнішніх дверей; утеплення і оновлення фасадів; перепланування квартир із застосуванням сучасних матеріалів [8,9]. Серед описаних в публікаціях методик досліджень використання експериментально-статистичного моделювання дозволяє отримати адекватні результати 3 мінімальними трудовими витратами [10]. 


\section{Формування мети статті}

Метою досліджень є визначення ефективних організаційних рішень реконструкції житлового будинку, шляхом створення та дослідження абстрактних моделей реконструкції при одночасному впливі факторів на показник рентабельності реконструкції.

\section{Виклад основного матеріалу}

Дослідження впливу факторів на показник рентабельності реконструкції проводились на прикладі реконструкції житлового будинку типової серії 1$438_{2.5}-7$ в використанням математичної теорії планування експерименту.

На основі об'ємно-планувальних та конструктивних рішень будинку був визначений перелік основних робіт та розраховані обсяги робіт. Була створена інформаційна модель у вигляді кошторису в програмі АВК-5(3.2.2) за цінами 2016 року.

Аналіз літературних джерел дозволив виділити основні фактори, що впливають на реконструкцію: кількість робочих годин на тиждень, ступінь суміщення робіт, частка заміни прорізів та комунікацій. Відповідно до класичної теорії планування скороченого експерименту, варійовані фактори повинні знаходяться в діапазоні -1; $0 ;+1$. Нижче детально представлений кожен фактор та діапазони варіювання.

Перший фактор - кількість робочих годин на тиждень $\left(\mathrm{X}_{1}\right)$ залежить від кількості робочих днів на тиждень і кількості робочих годин на день[11].

Прийнята кількість робочих годин на тиждень становить: 40год.; 80 год.; 112год.

Другий фактор - ступінь суміщення робіт $\left(\mathrm{X}_{2}\right)$ представляє собою відношення тривалості періоду реконструкції до суми тривалості робіт на кожній захватці (формула 1) характеризується коефіцієнтом суміщення і коливається в межах 0,15;0,2;0,25.

$$
\mathrm{X}_{2}=k_{\text {сов }}=\frac{\mathrm{T}_{\mathrm{c}}}{\sum_{1}^{N} * \sum_{1}^{n} t_{i}}
$$

де:

Тс - тривалість періоду реконструкції, дн;

$\mathrm{N}$ - кількість процесів;

n - кількість захваток при організації потоку;

$\mathrm{t}_{\mathrm{i}}$ - тривалість і-го потоку, дн.

Третій фактор - необхідна частка заміни прорізів $\left(\mathrm{X}_{3}\right)$ визначався на основі візуального огляду подібних будинків і складає 20\%; 50\%; 80\% від загального обсягу прорізів.

Четвертий фактор - необхідна частка заміни комунікацій $\left(\mathrm{X}_{4}\right)$ залежить від кількості під'їздів та стояків в розглянутій будівлі, та змінюється в межах: 8,33\%; 50\%; 91,66\% від загального обсягу.

Діапазон варіювання двох останніх факторів пов'язаний 3 самостійною заміною мешканцями окремих елементів протягом експлуатації будинку.

Показник рентабельності реконструкції житлового будинку при умові відселення мешканців під час проведення робіт напряму залежить від тривалості та вартості реконструкції. За допомогою програми Microsoft Project на основі трудомісткості робіт були побудовані графічні моделі реконструкції при одночасному впливі перших двох факторів згідно плану чисельного експерименту (Табл.1). Варіювання двох останніх факторів не впливають на тривалість проведення робіт, оскільки роботи по заміні прорізів та комунікацій не розташовані на критичному шляху лінійного графіку.

Таблиця 1

План експерименту і вплив варійованих факторів $\mathrm{X}_{1}$ i $\mathrm{X}_{2}$ на показник тривалості реконструкції житлового будинку $\left(\mathrm{Y}_{1}\right)$, умова реконструкції - відселення мешканців під час проведення робіт

\begin{tabular}{|c|c|c|c|c|c|}
\hline \multirow{2}{*}{$\begin{array}{c}\text { № } \\
\text { точки }\end{array}$} & \multicolumn{2}{|c|}{ Кодовані фактори } & \multicolumn{2}{|c|}{ Натурні фактори } & Показники \\
\cline { 2 - 6 } & $\begin{array}{c}\mathrm{X}_{1}-\text { кількість } \\
\text { нобочих годин }\end{array}$ & $\begin{array}{c}\mathrm{X}_{2} \text { коефіцієнт } \\
\text { суміщення } \\
\text { робіт }\end{array}$ & $\begin{array}{c}\mathrm{X}_{1} \text { - кількість } \\
\text { робочих годин на } \\
\text { тиждень } \\
\text { (год) }\end{array}$ & $\begin{array}{c}\mathrm{X}_{2} \text { коефіцієнт } \\
\text { суміщення } \\
\text { робіт }\end{array}$ & $\begin{array}{c}\mathrm{Y}_{1} \text { - Тривалість } \\
\text { реконструкції, } \\
\text { (дн) }\end{array}$ \\
\hline 1. & -1 & -1 & 40 & 0,15 & 484 \\
\hline 2. & -1 & 0 & 40 & 0,2 & 670 \\
\hline 3. & -1 & 1 & 40 & 0,25 & 807 \\
\hline 4. & 0,11 & -1 & 80 & 0,15 & 243 \\
\hline 5. & 0,11 & 0 & 80 & 0,2 & 335 \\
\hline 6. & 0,11 & 1 & 80 & 0,15 & 173 \\
\hline 7. & 1 & -1 & 112 & 0,2 & 239 \\
\hline 8. & 1 & 0 & 112 & 0,25 & 288 \\
\hline 9. & 1 & 1 & 112 & & \\
\hline
\end{tabular}


На вартість реконструкції впливають: зміни обсягів основних робіт (третій та четвертий фактор), витрати на перепланування квартир на 1 поверсі та витрати за оренду тимчасового житла для мешканців. Вартість реконструкції визначалась за формулою:

$$
\mathrm{C}=\mathrm{C}_{\text {рек.рбр }}+\mathrm{C}_{\text {кв.п }}+\mathrm{C}_{\text {т.ж }}
$$

де:

C - вартість реконструкції об'єкта, грн.;

$\mathrm{C}_{\text {рек .рбр }}-$ вартість ремонтно-будівельних робіт за кошторисом, грн.;

$\mathrm{C}_{\text {кв.п }}-$ витрати на покупку квартир на 1 поверсі, пов'язані з переплануванням квартир для прибудови ліфтової шахти, грн.;

$\mathrm{C}_{\text {т.ж }}-$ витрати на оплату тимчасового житла мешканцям під час реконструкції, грн.

$$
\mathrm{C}_{\mathrm{T} . \%}=\mathrm{C}_{\mathrm{T} . \% .} * \mathrm{~T}_{\text {рек }}
$$

де:

$\mathrm{C}_{\text {т.ж. }}$ - щомісячні витрати на оплату тимчасового житла в період реконструкції для мешканців, грн.;

$\mathrm{T}_{\text {рек }}$ - тривалість реконструкції, міс.

Рентабельність реконструкції обернено пропорційна вартості робіт. Розрахунок виконувався за формулою 4:

$$
\mathrm{P}=\frac{\Pi}{\mathrm{C}} * 100
$$

де:

P - рентабельність, \%;

П - прибуток об'єкта реконструкції, тис. грн.;

С - вартість об'єкта реконструкції, тис. грн.

Прибуток реконструкції розраховується за формулою 5:

$$
\Pi=\mathrm{C}_{\Pi \mathrm{p}}-\mathrm{C}
$$

де:

П -прибуток об'єкта реконструкції, грн.;

$\mathrm{C}_{\text {пр. }}$ - прибуток від продажу нових квартир на 1,6,7 поверсі після реконструкції.

Розрахунок показників вартості та рентабельності реконструкції при одночасному впливі чотирьох факторів представлений в таблиці 2.

Вплив факторів на показник рентабельності визначався за допомогою програми COMРЕХ. Описання залежності представлено у вигляді аналітичної формули :

$$
\begin{gathered}
Y_{3}=7,531+10,402 X_{1}-3,98 X_{1}^{2}+1,58 X_{1} X_{2} \\
-0,44 X_{1} X_{3}-0,064 X_{1} X_{4}-5,108 X_{2}-0,904 X_{2}^{2} \\
+0,241 X_{2} X_{3}+0,031 X_{2} X_{4}-2,28 X_{3}+0,144 X_{3}^{2} \\
+0,015 X_{3} X_{4}-0,33 X_{4}+ \\
0,074 X_{4}^{2}
\end{gathered}
$$

$$
\text { Критерий Fisher }=1.7520
$$

Критерий $\mathrm{Fkr}=1.7520$

$$
\mathrm{Kzm}=1.000 \mathrm{NSe}=0.179
$$

Аналіз отриманої математичної залежності показав, що найбільший вплив на рентабельність реконструкції будинку надають фактор $\mathrm{X}_{1}$ (кількість робочих годин на тиждень). Позитивний знак коефіцієнта $\mathrm{X}_{1}$ вказує що зміна цього фактора прямо пропорційна зміні рентабельності $\left(\mathrm{Y}_{3}\right)$. В двоє менший вплив надає фактор $\mathrm{X}_{2}$ (коефіцієнт суміщення робіт), i в п'ять разів менший вплив фактор $\mathrm{X}_{3}$ (необхідна частка заміни прорізів). Вплив фактора $\mathrm{X}_{4}$ (необхідна частка заміни комунікацій) незначний. Відємні знаки коефіцієнтів факторів $\mathrm{X}_{2}, \mathrm{X}_{3}, \mathrm{X}_{4}$ показують, що їх вплив обернено пропорційний збільшенню рентабельності $\left(\mathrm{Y}_{3}\right)$.

Графічне зображення впливу представлено на діаграмах (Рис.1,2). Побудова однофакторних моделей діаграм виконується в двох граничних екстремальних варіантах (Рис.1). Верхні криві, побудовані в площинах $\left(\mathrm{Y}, \mathrm{X}_{\mathrm{i}}\right)$, що проходять через точку 3 максимальним значенням функції Ү. У цьому випадку всі інші фактори, фіксуються на рівні мінімального значення показника Ү. Криві, в нижній частині побудовані в тих же площинах, але через точку 3 мінімальним значенням функції Ү. У нижній частині діаграми ранжирування показують ступінь впливу кожного з факторів на показник в областях мінімуму і максимуму функції. При розгляді впливу кожного $з$ факторів у зоні екстремумів передбачається фіксація факторів ,що залишились на середньому рівні (0-х значеннях).

Діаграми ранжирування по максимуму і мінімум в областях функції показують, що найбільший вплив на рентабельність реконструкції житлового будинку надає фактор $\mathrm{X}_{1}$ (кількість робочих годин на тиждень) - 100\% (Рис.1). Вплив інших факторів $\mathrm{X}_{2}$ (коефіцієнт суміщення робіт), $\mathrm{X}_{3}$ (необхідна частка заміни прорізів), $\mathrm{X}_{4}$ (необхідна частка заміни комунікації) в зоні максимуму однаковий і становить $61 \%$. У зоні мінімуму фактори $\mathrm{X}_{2}$ (коефіцієнт суміщення робіт), $\mathrm{X}_{3}$ (необхідна частка заміни прорізів) мають близьке вплив $\mathrm{X}_{2}-40 \%, \mathrm{X}_{3}-31 \%$. Фактор $\mathrm{X}_{4}$ (необхідна частка заміни комунікації) в зоні максимуму впливу майже не має - менше $5 \%$ На графіках в зоні максимуму і мінімуму видно, що вплив факторів $\mathrm{X}_{1}$ i $\mathrm{X}_{2}$ представлено у вигляді парабол, а вплив факторів $\mathrm{X}_{3}$ i $\mathrm{X}_{4}$ носить лінійний характер. 
Таблиця 2

План експерименту і вплив варійованих факторів $\left(\mathrm{X}_{1}, \mathrm{X}_{2}, \mathrm{X}_{3}\right.$ i $\left.\mathrm{X}_{4}\right)$ на показники дослідження вартості реконструкції $\left(\mathrm{Y}_{2}\right)$ і рентабельності $\left(\mathrm{Y}_{3}\right)$, умова реконструкції - відселення мешканців під час проведення робіт

\begin{tabular}{|c|c|c|c|c|c|c|c|c|c|c|}
\hline \multirow[b]{2}{*}{ 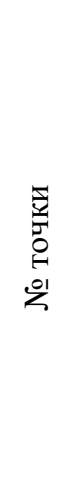 } & \multicolumn{4}{|c|}{ Кодовані фактори } & \multicolumn{4}{|c|}{ Натурні фактори } & \multicolumn{2}{|c|}{ Показники } \\
\hline & 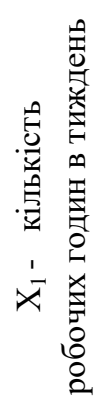 & 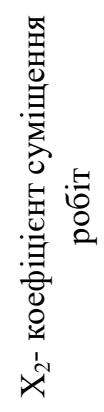 & 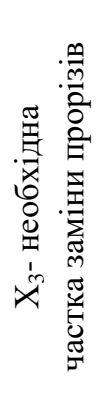 & 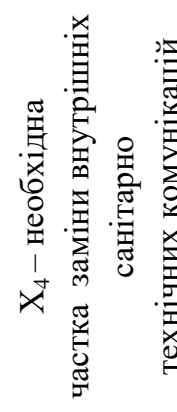 & 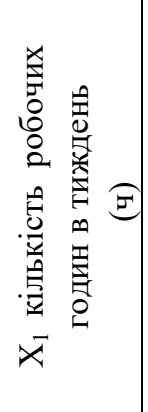 & 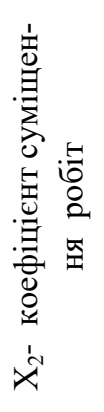 & 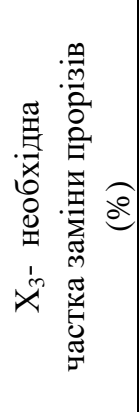 & 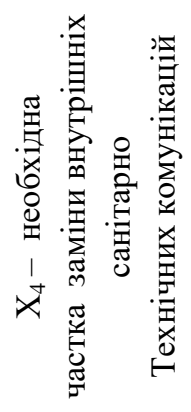 & 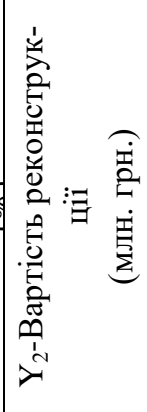 & 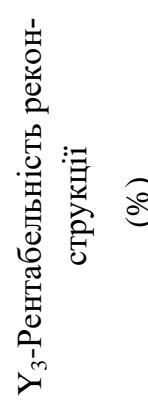 \\
\hline 1 & 1 & 1 & 1 & 1 & 112 & 0,25 & 80 & 91,66 & 25,17 & 8,56 \\
\hline 2 & 1 & 1 & 1 & -1 & 112 & 0,25 & 80 & 8,33 & 25,0 & 9,26 \\
\hline 3 & 1 & 1 & -1 & 1 & 112 & 0,25 & 20 & 91,66 & 24,05 & 13,6 \\
\hline 4 & 1 & 1 & -1 & -1 & 112 & 0,25 & 20 & 8,33 & 23,89 & 14,37 \\
\hline 5 & 1 & -1 & 1 & 1 & 112 & 0,15 & 80 & 91,66 & 23,69 & 15,34 \\
\hline 6 & 1 & -1 & 1 & -1 & 112 & 0,15 & 80 & 8,33 & 23,52 & 16,13 \\
\hline 7 & 1 & -1 & -1 & 1 & 112 & 0,15 & 20 & 91,66 & 22,57 & 21,05 \\
\hline 8 & 1 & -1 & -1 & -1 & 112 & 0,15 & 20 & 8,33 & 22,41 & 21,93 \\
\hline 9 & -1 & 1 & 1 & 1 & 40 & 0,25 & 80 & 91,66 & 31,84 & $-14,21$ \\
\hline 10 & -1 & 1 & 1 & -1 & 40 & 0,25 & 80 & 8,33 & 31,68 & $-13,77$ \\
\hline 11 & -1 & 1 & -1 & 1 & 40 & 0,25 & 20 & 91,66 & 30,72 & $-11,08$ \\
\hline 12 & -1 & 1 & -1 & -1 & 40 & 0,25 & 20 & 8,33 & 30,56 & $-10,61$ \\
\hline 13 & -1 & -1 & 1 & 1 & 40 & 0,15 & 80 & 91,66 & 27,69 & $-1,33$ \\
\hline 14 & -1 & -1 & 1 & -1 & 40 & 0,15 & 80 & 8,33 & 27,52 & $-0,75$ \\
\hline 15 & -1 & -1 & -1 & 1 & 40 & 0,15 & 20 & 91,66 & 26,57 & 2,82 \\
\hline 16 & -1 & -1 & -1 & -1 & 40 & 0,15 & 20 & 8,33 & 26,41 & 3,45 \\
\hline 17 & 1 & 0 & 0 & 0 & 112 & 0,2 & 50 & 50 & 23,9 & 17 \\
\hline 18 & -1 & 0 & 0 & 0 & 40 & 0,2 & 50 & 50 & 29,44 & $-7,22$ \\
\hline 19 & 0,11 & 1 & 0 & 0 & 80 & 0,25 & 50 & 50 & 26,02 & 4,98 \\
\hline 20 & 0,11 & -1 & 0 & 0 & 80 & 0,15 & 50 & 50 & 23,95 & 14,06 \\
\hline 21 & 0,11 & 0 & 1 & 0 & 80 & 0,2 & 80 & 50 & 25,69 & 6,34 \\
\hline 22 & 0,11 & 0 & 0 & 1 & 80 & 0,2 & 50 & 91,66 & 25,22 & 8,34 \\
\hline 23 & 0,11 & 0 & -1 & 0 & 80 & 0,2 & 20 & 50 & 24,57 & 11,18 \\
\hline 24 & 0,11 & 0 & 0 & -1 & 80 & 0,2 & 50 & 8,33 & 25,05 & 9,04 \\
\hline 25 & 0,11 & 0 & 0 & 0 & 80 & 0,2 & 50 & 50 & 25,14 & 8,69 \\
\hline
\end{tabular}


Впшив факторів в зоні максимуму та мінімуму на рентабельність реконструкції

Y3
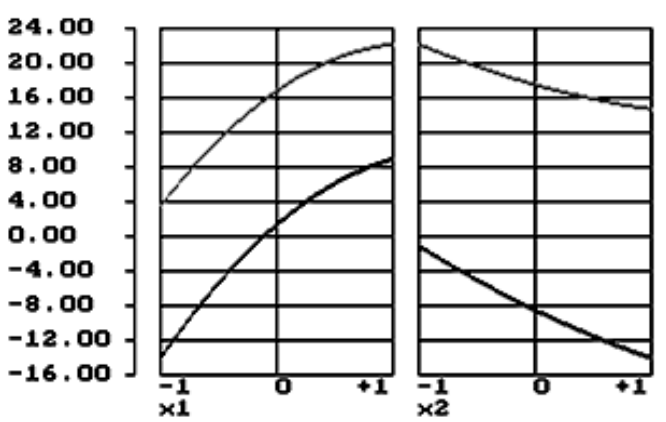

Ранжування по максимуму

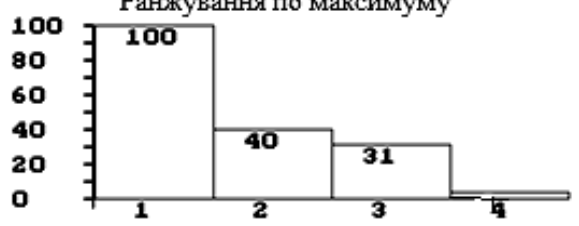

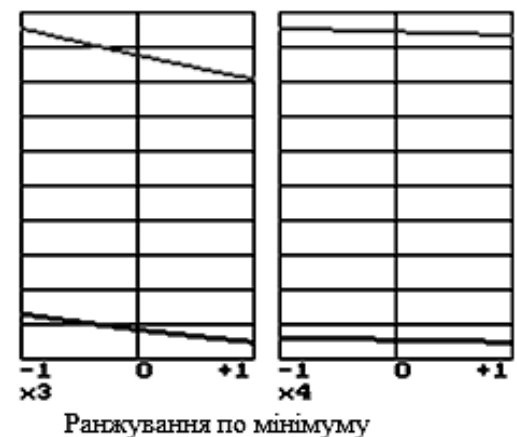

Ранжування по мінімуму

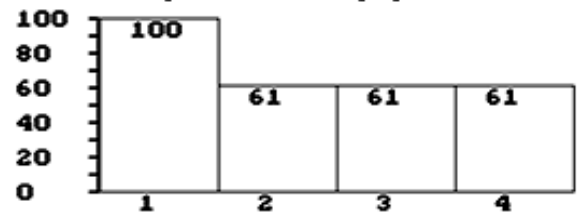

Рис.1 Однофакторна діаграма впливу факторів $\left(\mathrm{X}_{1}, \mathrm{X}_{2}, \mathrm{X}_{3}, \mathrm{X}_{4}\right)$ на рентабельність реконструкції ( $\left.\mathrm{Y}_{3}\right)$ за умови відселення мешканців

Вплив всіх 4-х факторів $\mathrm{X}_{1}$ (кількість робочих годин на тиждень), $\mathrm{X}_{2}$ (коефіцієнт суміщення робіт), $\mathrm{X}_{3}$ (необхідна частка заміни прорізів) і $\mathrm{X}_{4}$ (необхідна частка заміни комунікацій) на рентабельність реконструкції ( $\left.\mathrm{Y}_{3}\right)$ при різному їх поєднанні відображено в діаграмі «квадрат на квадраті» (Рис.2). Для побу- дови діаграми будуються 9 двофакторних діаграм (вплив факторів $\mathrm{X}_{1}$ i $\mathrm{X}_{2}$ ), які розташовуються на основному квадраті. Основний квадрат враховує вплив факторів $\mathrm{X}_{3}$ i $\mathrm{X}_{4}$. На побудованій діаграмі зміна ї рентабельності реконструкції зображена ізолініями кроком

$5 \%$.

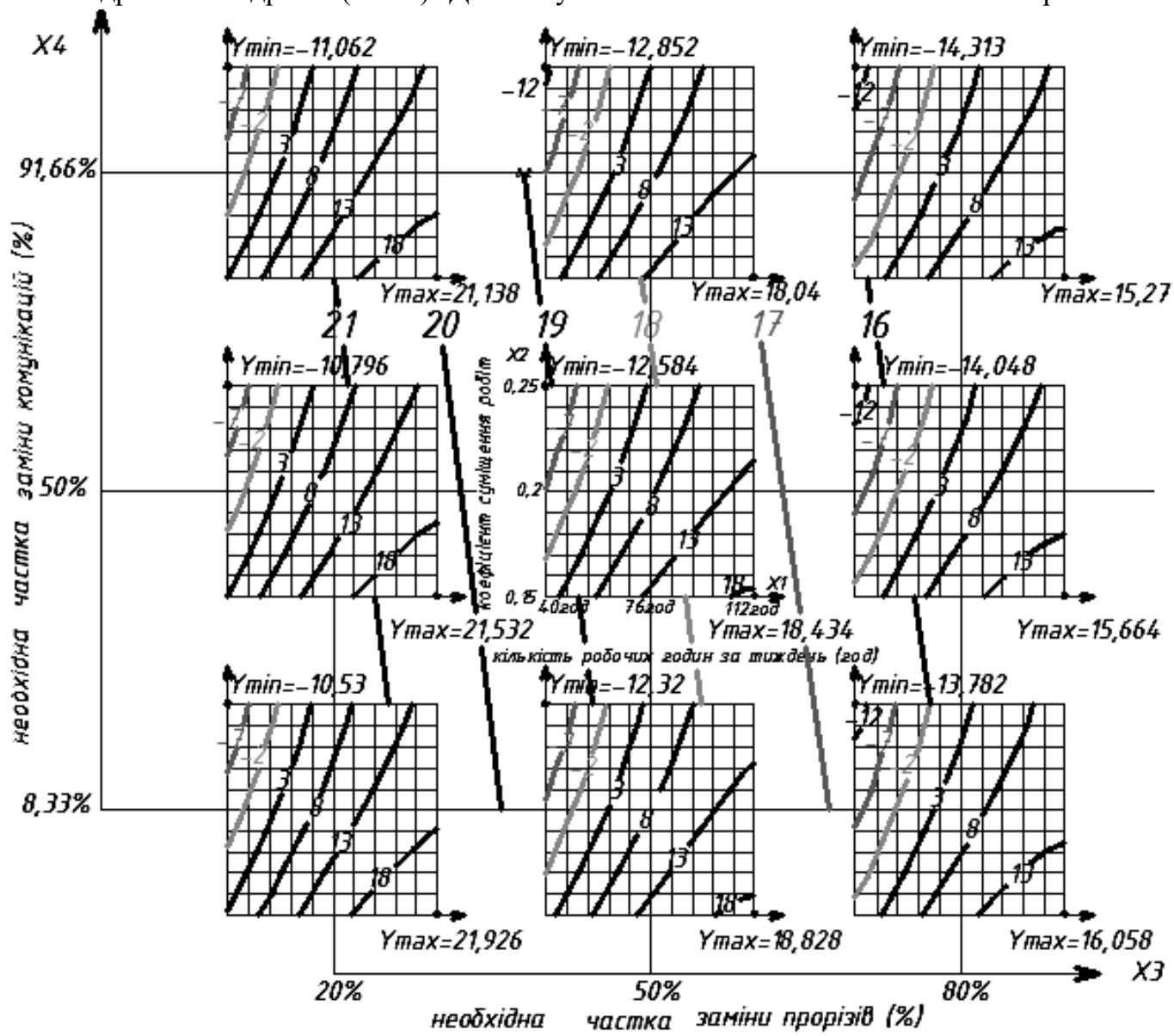

Рис. 2. Діаграма «квадрат на квадраті» відображає вплив факторів $\left(\mathrm{X}_{1}, \mathrm{X}_{2}, \mathrm{X}_{3}, \mathrm{X}_{4}\right)$ на рентабельність реконструкції $\left(\mathrm{Y}_{3}\right)$ за умови відселення мешканців 
Межа ефективності показника рентабельності реконструкції прийнята на основі [12]. Для державних інвестиції показник 8\% і вище показує прибутковість проєкту. Розташування ізоліній 8\% та більше дозволяє зробити висновок, що при будь-якому поєднанні чотирьох факторів реконструкція не буде збитковою. Максимальні показники рентабельності реконструкції $\left(\mathrm{Y}_{3}\right)$ можна досягти при поєднанні факторів $\mathrm{X}_{1}$ від -1 до 0 (від 40 до 76 робочих годин на тиждень), при $\mathrm{X}_{2}$ від -1 до 0 (коефіцієнт суміщення робіт від 0,15 до 0,25 ), при $\mathrm{X}_{3}$ від -1 до 0 (необхідна частка заміни прорізів від $20 \%$ до $50 \%$ ) і при $\mathrm{X}_{4}$ від -1 до +1 (необхідна частка заміни комунікацій $91,66 \%)$.

\section{Висновки}

Вперше на основі експериментальностатистичного моделювання були отримані залежності між організаційно-технологічними факторами та показником рентабельності реконструкції.

Аналіз графічного зображення залежності показника рентабельності від факторів показав, що реконструкція 3 відселенням мешканців під час виконання робіт перевищує $8 \%$ і являється прибутковою.

Найбільший ефект досягається при поєднанні факторів :

- $\mathrm{X}_{1}$ від -1 до 0 (від 40 до 76 робочих годин на тиждень),

- $\mathrm{X}_{2}$ від -1 до 0 (коефіцієнт суміщення робіт від 0,15 до 0,25),

- $\mathrm{X}_{3}$ від -1 до 0 (необхідна частка заміни прорізів від 20\% до $50 \%$ ),

- $\mathrm{X}_{4}$ від -1 до +1 (необхідна частка заміни комунікацій 91,66\%).

\section{Перспективи і подальший розвиток}

Методика дослідження може бути використана для дослідження інших показників реконструкції житлових будинків перших масових серій. Отримані результати дозволяють розробити рекомендації проведення реконструкції житлових будинків аналогічних типових серій.

\section{Література}

1. Статистичний збірник «Регіони України» [Електронний ресурс] / Державна служба статистики Украӥни. Київ - Режим достуny : |www/ URL: http://www.ukrstat.gov.ua/druk/publicat/kat_u/2018/zb/11/zb_ rulch2018.pdf-2018. - Загл. с екрана.

2. Мāju pārbūves iespējas [Електронуий ресурс] / Parplanosana.lv. Arhitektūras un inženieru birojs. Rīga. Режим docmyny: |www| URL: http://www.parplanosana.lv/ru/paarplaanoshanas-varianti177781/1-467a-serija-staraja-litovka\#.Uxy1cT9_uSo. - 2012. - Загл. с екрана.
3. Натия Джохадзе Программа комплексной реабилитации жильхх домов массовой застройки первого поколения (на примере г. Тбилиси) [Электронный ресурс] / HeinrichBöll-Stiftung Tбілісі, - Режим доступу : |www/ URL: http://ge.boell.org/en/2005/01/16/programma-kompleksnoyreabilitacii-zhilyh-domov-massovoy-zastroyki-pervogopokoleniya-na-20142. . - Загл. с екрана.

4. Stefan Forster architekten gmbh [Електронний pecypc] / Baunetz-architekten oфiųiŭнuй . -Frankfurt am Main,2020 - Режим доступy : |www/ URL: https://www.baunetz-architekten.de/stefan-forster-

architekten/31237- Загл. с екрана.

5. Офіиійний сайт німецького архітектурного бюро Stefan Forster Architekten [Электронный pecypc]:http://www.stefan-forster-architekten.de

6. Перькова, М. А. Реконструкция типовых серий жильх зданий [Текст] / Перькова М.А. // Молодежь и наука: сборник материалов IX Всероссийской научнотехнической конференции студентов, аспирантов и молодых ученых с международным участием, посвященной 385-летию со дня основания г. Красноярска. Сибирский федеральныии ун-т. - Красноярск: 2013.

7. Куркин, Н.П. Диагностика технического состояния жильхх зданий [Текст] : Монография / Н.П. Куркин, М.С. Розенфельд, А.Г. Неверов, М.Н. Волошко ;под ред. Н.П. Куркина. - Луганск: Янтарь, 2012. -368c.

8. Комплекс градостроительной политики и строительства города Москвы. Какие серии домов подлежат сносу в Москве. [Электронный ресурс] // Новостройки СанктПетербурга и области - Режим доступа: |www/ URL: https://spbnovo.ru/kak/kakie-serii-domov-podlezhat-snosu-vmoskve.html-2008 - Загл. с екрана

9. Афанасьев, А. А. Реконструкиия жильх зданий [Электронный ресурс] : в 2-х частях / А. А. Афанасьев, Е. П. Матвеев. // Москва, Часть II. Технологии реконструкиии жильхх зданий и надстройки - Режим доступа: |www/ URL: http://www.complexdoc.ru/ntdpdf/537193/rekonstruktsiy a_zhilykh_zdanii_chast_II_tekhnologii_rekonstruktsii_zhilykh. pdf/2008. - Загл. с екрана

10. Гончаренко, Д. Ф. Определение показателей гражданского строительства в Одессе при вариантном организационно-технологическом проектировании [Текст] / Д. Ф.Гончаренко, И. А. Менейлюк. // Науковий вісник будівництва., Серія «Будівництво» Харківського національного університету будівництва та архітектури - 2019, -T.2,№ 2(96). - C.197-203. ISSN 2311-7257

11. Кодекс законов о труде Украины от 10.12 .71 г. №322VIII [Текст] / C изменениями и дополнениями, внесенными Законами Украины, в том числе Законом Украины от 19.04.2011 2. №3231-VI

12. Валицкий, С.В. Экономика строительства [Текст] / С.В. Валицкий, О.С. Голубова - Минск.: БНТУ, 2009. $180 \mathrm{c}$.

\section{References}

1. Public service of Ukrainian statistics.(2018) Statistical digest "Regions of Ukraine" State Statistics Service of Ukraine. Kiev - $\quad$ Retrieved from http://www.ukrstat.gov.ua/druk/publicat/kat_u/2018/zb/11/zb_ ru1ch2018.pdf

2. Variants of replanning of series houses (2012). Parplanosana.lv Architectural and engineering office. Riga. Retrieved 
from http://www.parplanosana.lv/ru/paarplaanoshanasvarianti-177781/1-467a-serija-staraja-litovka\#.Uxy1cT9_uSo 3. Dzhokhadze Natiya (2014). Programma kompleksnoy reabilitacii zhilyh domov massovoy zastroyki pervogo pokoleniya. [The program of complex rehabilitation of the dwellings of mass housing development of first generation (by example of Tbilitsi)]. Heinrich-Böll-Stiftung Tbilitsi. Retrieved from http://ge.boell.org/en/2005/01/16/programmakompleksnoy-reabilitacii-zhilyh-domov-massovoy-zastroykipervogo-pokoleniya-na.

4. Stefan Forster Architect gmbh (2020). Baunets architect. Frankfurt on the Main. Retrieved from https://www.baunetz-architekten.de/stefan-forsterarchitekten/31237.

5. Офіційний сайт німецького архітектурного бюро Stefan Forster Architekten . Retrieved from http://www.stefanforster-architekten.de

6. Perkova, M.A.(2013). Rekonstruksia tipovykh serii zhilykh zdaniy [Reconstruction of typical series of dwellings. Youth and science: source book of IX All-Russian scientific-technical conference of students, post-graduates and young scientists dedicated to 385th-anniversary from the foundation of Krasnoyarsk city. Siberian federal university. Krasnoyarsk [ in Russian]

7. Kurkin. N.P (2012). Diagnostika tekhnicheskogo sostoyania zhilykh zdanii [Diagnostics of technical conditions of dwellings]. Luhansk [in Ukrainian]

8. Kompleks gradostroitelnoy politiki I stroitelstva horoda moskvyKakie serii domov podlezhat snosu v Moskve/(2008)/[ Complex of town planning policy and building of Moscow. What series of houses are to be demolished?]. Newly- erected buildings of St.Petersburg and region. Retrieved from https://spbnovo.ru/kak/kakie-serii-domov-podlezhat-snosu-vmoskve.html

9. Afanasiev, A.A . (2008) Rekonstruktsiya zhilykh zdanii [Reconstruction of dwellings]. Moscow, Retrieved from http://www.complexdoc.ru/ntdpdf/537193/rekonstruktsiya_zhi lykh_zdanii_chast_II_tekhnologii_rekonstruktsii_zhilykh.pdf/ 2008. [in Russian]

10. Honcharenko, D.F. (2019) Opredelenie pokazateley hrazhdanskogo stroitelstva $\mathrm{v}$ odesse pri variantnom organizatsionno-tekhnologitseskom proektirovanii [The definition of indexes of civil engineering in Odessa by variable organizational and technological projection]. Science herald of construction., Series "Construction". Kharkiv national university of building and architecture

11. Labour Code of Ukraine №322VIII C with amendments №3231-VI.2011

12. Valitskiy, S.V Ekonomika stroitelstva [Building economics]. Minsk.[in Russian].

Рецензент: д-р техн. наук проф. А.Ф. Петровський, Одеська державна академія будівництва та архітектури, Одеса, Україна

\section{Автор: ДУБЕЛЬТ Тетяна Михайлівна}

аспірант кафедри «Технологія будівельного виробниитвва»

Одеська державна академія будівниџтва та архітектури

E-mail-madam.tatiana3009@gmail.com

ID ORCID: http://orcid.org/0000-0003-2853-5704

\title{
THE STUDY OF IMPACT OF FACTORS ON PROFITABILITY INDEX OF RECONSTRUCTION OF THE DWELLINGS
}

\author{
T. Dubelt
}

Odessa State Academy of Building and Architecture, Ukraine

The article deals with the study of impact of organizational and technological factors on the index of reconstruction profitability of dwellings of first mass series on condition of habitants' eviction while doing operations. We find lack of information on the methodology of the study of such objects in informative sources. Factual dwellings' reconstruction has an incidental character and does not allow to define the impact of factors on the indexes of reconstruction because it takes place by fixed values of factors and limited quantities of objects. And as a consequence we find investors' unwillingness to put money into the reconstruction of the dwellings of typical series. The purpose of the study is to define the efficient solutions of reconstruction of the dwelling of typical series 1-438.5-7. The given task is solved by making abstract models of the series imitating reconstruction's operations by simultaneous impact of organizational and technological factors. While conducting the investigation we defined the factors and the levels of their variation that have impact on the dwellings' reconstruction. The plan of multiple experiment was elaborated considering the simultaneous effect of the given factors on reconstruction indexes. On the basis of the given series of dwelling we made informative and graphical models, and we also got the indexes of reconstruction. Graphical modeling allowed to obtain numerical values of operations' durability. Simultaneous impact of factors and the conditions of habitants' eviction defined numerical value of operations' cost. With the help of formula we obtained the value of profitability index. We defined the dependency of profitability index on varying factors using the methods of mathematical analysis. It is shown in the form of dependency charts and is described by mathematical formula. We substantiated the admissible numerical values of profitability index of reconstruction of the dwellings of first mass series. The conclusions about effective solutions on reconstruction of such dwellings are made by graphical image and the areas of effective solutions are defined

Keywords: factors, reconstruction indexes, reconstruction models, mathematical analysis, charts of dependen$c y$. 